\title{
Knowledge Sharing Challenges during Post-Merger Integration: The Role of Boundary Spanners and of Organizational Identity
}

\author{
Dragos Vieru $^{1} \&$ Suzanne Rivard ${ }^{2}$ \\ ${ }^{1}$ École des Sciences de l'Administration, Distance Learning University of Quebec (Télé-Université), Montréal, \\ Canada \\ ${ }^{2}$ Department of Information Technologies, HEC Montréal, Montréal, Canada \\ Correspondence: Dragos Vieru, École des Sciences de l'Administration, Distance Learning University of Quebec, \\ 5800 rue St-Denis, Suite 1105, Montreal, QC, H2S3L5, Canada. Tel: 1-514-576-2168. E-mail: \\ dragos.vieru@teluq.ca
}

Received: July 2, 2015

Accepted: August 28, 2015

Online Published: October 28, 2015

doi:10.5539/ijbm.v10n11p1

URL: http://dx.doi.org/10.5539/ijbm.v10n11p1

\begin{abstract}
When organizations merge, information systems (IS) need to be integrated to span the demarcations between the previously independent entities, be to bridge the pre-merger ISs or as new, single IS. Although research stresses the important role played by ISs in support of the combined organizations, there is a paucity of studies on the process of IS integration. Grounded in the practice perspective of knowledge and on the concept of organizational identity, we first propose a conceptual framework that conjectures about effective knowledge sharing processes, boundary objects and the role that boundary spanners are expected to play if they are to be effective. Then, we assess the relational dynamics suggested by our framework in four existing case studies from the academic literature that present rich post-merger IS integration data.
\end{abstract}

Keywords: post-merger integration, IS integration, knowledge sharing, organizational identity, boundary spanners

\section{Introduction}

Mergers and acquisitions represent a major strategic tool for business growth and market repositioning (Weber \& Tarba, 2012). In line with the literature, we use the term 'merger' hereafter to refer to mergers and acquisitions (Wijnhoven, Spil, Stegwee, \& Fa, 2006). Post-merger integration (PMI) is the process of actual merger value-creation that will hopefully materialize when the organizations are amalgamated (Larsson \& Finkelstein, 1999). Despite the anticipated benefits of a merger, high failure rates have been reported (Yetton, Henningsson, \& Bjorn-Andersen, 2013), which suggests inherent complexities in managing PMI (Mehta \& Hirschheim, 2007; Vieru \& Rivard, 2014b) and associated challenges that are yet to be fully understood (Vaara \& Monin, 2010).

The literature emphasizes information technology (IT) integration as a critical endeavor of PMI (Wijnhoven et al., 2006; Yetton et al., 2013) and a decisive enabler in fostering rapid business integration and full realization of expected benefits (Tanriverdi \& Uysal, 2011; Sarrazin \& West, 2011). Some even consider a lack of successful IT integration as one of the main reasons for merger failure (Henningsson \& Yetton 2011; Yetton et al., 2013).

IT integration may pertain to five types of IT resources: infrastructures, applications and data, human resource management practices, vendor management, and strategy-making practices (Tanriverdi \& Uysal, 2011). This paper focuses on the integration of applications and data - i.e., information systems (IS) integration-, which can take three main forms (Wijnhoven et al., 2006): 1) complete integration: merging entities' ISs are completely amalgamated (Mehta \& Hirschheim, 2007); 2) partial integration: based on strategic needs, the new organization choose to integrate some systems while keeping others untouched (Brown, Clancy, \& Scholer, 2003; Seddon, Reynolds, \& Willcocks, 2010); and 3) marginal integration (co-existence), where pre-merger ISs, enabling unique business processes, need to be retained (Yetton et al., 2013).

Extant studies generally adopt a contingency perspective to recommend different degrees of IS integration, according to: IS requirements, business objectives and merger goal (Wijnhoven et al., 2006); level of strategic importance of the IS function and organizational IS learning (Merali \& McKiernan, 1993); or IS/IT-business alignment requirements (Mehta \& Hirschheim, 2007; Henningsson \& Carlsson, 2011; Yetton et al., 2013). 
Notwithstanding the value of this literature and its contribution to the advancement of knowledge on IS integration, we notice that most studies have focused on the conditions for successful IS integration, thus neglecting somewhat the IS integration process itself, i.e., "the process that aims at making the changes required to allow the merged organizations to function as a whole" (Mehta \& Hirschheim, 2007, p. 145). Given the numerous issues that arise during PMI, research seeking to expand knowledge on the IS integration process, improve our understanding of the PMI process, identify its key challenges and propose research directions for addressing these challenges is deemed important (Vieru \& Rivard, 2014a). We aim at making these contributions by proposing a theoretical framework focused on the knowledge sharing during IS integration projects.

The PMI literature suggests that integrating information systems is difficult because of the incompatibility of the merging parties' ISs (Mehta \& Hirschheim, 2007; Yetton et al., 2013). In addition to technological difficulties, collaboration and knowledge sharing challenges are likely to emerge since the actors involved abide by different local, social and cultural rules (Empson, 2001). Extant research on mergers depicts a clear connection between knowledge sharing between the members of merging parties and value creation (e.g., Graebner, 2004). In parallel, the IS literature recognizes that a major reason for the failure of some ISs to deliver the expected benefits is the lack of effective knowledge sharing among IS project participants (Orlikowski, 2002; Luna-Reyes, Zhang, Gil-Garcia, \& Cresswell, 2005).

Notwithstanding recent research on IS challenges in PMI (Henningsson \& Carlsson, 2011; Yetton et al., 2013), few studies have focused on the challenges associated with cross-boundary knowledge sharing during PMI (Vieru \& Rivard, 2014a). To address this, we engage in theory development and we propose a conceptual framework based on two theoretical foundations-knowledge sharing practices across boundaries and organizational identity-and informed by a typology of PMI approaches (Marks \& Mirvis, 2001) to answer the following questions:

What key knowledge-sharing challenges are organizations likely to face when they undertake IS integration during PMI? How can these challenges be addressed?

Our choice of knowledge sharing practices across boundaries as a theoretical lens is based on studies that have shown, albeit not in a PMI context, that knowledge sharing during IS projects involving individuals engaged in different practices is both critical and difficult (Luna-Reyes et al., 2005; Levina \& Vaast, 2005). We adopt a practice perspective, which conceptualizes knowledge as an integral part of daily work practices (Carlile, 2002). Under this perspective, individuals (or agents) who belong to the same field of practice (e.g., a business unit) share a set of work practices and pursue a joint interest (Levina \& Vaast, 2005). Individuals from different practices have different assumptions and interpretations of the organizational context (Brown \& Duguid, 2001). While in general knowledge sharing is a difficult task (Brown, Dennis, Burley, \& Arling, 2013; Yuan, Zhao, Liao, \& Chi, 2013), knowledge sharing across the boundaries that separate different practices is even more challenging (Carlile, 2004; Vieru \& Rivard, 2014b).

Our second theoretical lens is organizational identity, which refers to mental representations of how organizational members define themselves as a social group in terms of practices, norms, and values and understand themselves to be different from members of other organizations (Corley \& Gioia, 2004). Research suggests that organizational identity may increase the challenges of knowledge sharing during PMI (Schweizer, 2005; Vieru \& Rivard, 2014b). It suggests that the members of merging organizations may feel that their core organizational values and practices are endangered by the inculcation of a new organizational identity (Langley, Golden-Biddle, Reay, Denis, Lamothe, \& Gervais, 2012; Clark, Gioia, Ketchen, \& Thomas, 2010).

Our study offers a theoretical explanation of how a given PMI approach influences the conditions surrounding the IS and conjectures about effective knowledge sharing processes, boundary objects and the role that boundary spanners are expected to play if they are to be effective. It provides "an explanation of how, why, and when things happened, relying on varying views of causality and methods for argumentation" (Gregor, 2006, p. 619). Engaged in a theory-building effort, we put "less emphasis on the synthesis of prior literature and more emphasis on theoretical development" (Rivard, 2014, p. iv). Thus, the following two sections briefly describe our theoretical foundations followed by a detailed theorization of the conceptual framework. Finally, we offer conclusions and recommendations for future research.

\section{Theoretical Foundations}

\subsection{Post-Merger Integration Approaches}

The literature on PMI considers the choice of integration approach as one of a merger's most important strategic decisions and as a critical determinant of the PMI outcomes (Weber \& Tarba, 2012; Yetton et al., 2013; Vieru \& 
Rivard, 2014a). Researchers have proposed different typologies of PMI approaches (e.g., Haspelagh \& Jamison, 1991; Marks \& Mirvis, 2001) based on the level of integration of merging organizations. We adopt Marks and Mirvis' typology (2001) as it focuses on the level of change in business processes and practices, which is particularly relevant for IS integration. This typology identifies four ideal-type approaches: preservation, absorption, symbiosis, and transformation. Preservation requires minimal change in the merging organizations, as it preserves the demarcation between the merging organizations and keeps intact the strategic capabilities of each merging party. Absorption corresponds to a situation where one organization imposes its work practices, norms and culture on the other parties, while experiencing itself only minimal change. The Symbiotic approach involves a gradual blending of best practices from the merging organizations and a certain degree of change in all merging parties. Under Transformation, organizations are integrated by developing totally new, common practices and culture.

\subsection{A Practice Perspective on Knowledge Sharing Across Boundaries}

In this study we adopt the practice perspective of knowledge, which proved particularly useful when studying collaborative initiatives involving members from different organizations (Suchman, 2002; Levina \& Vaast, 2005), albeit not in a PMI context. This perspective conceptualizes knowledge and practice as being reciprocally constitutive (Orlikowski, 2002; Levina \& Vaast, 2005; McIver, Lengnick-Hall, \& Ramachandran, 2013) with knowledge being "localized, embedded and invested in practice" (Carlile, 2002, p. 442). Our study focuses on seven key concepts of the practice perspective: practice, field of practice, boundaries, symbolic capital, knowledge sharing processes, boundary spanners and boundary objects.

The term practice refers to "coordinated activities of individuals and groups in doing their 'real work' as it is informed by a particular organizational or group context" (Cook \& Brown, 1999, p. 387). Within a field of practice, agents are differentiated by their status, which is defined by unequal access to three fundamental types of capital: economic capital (e.g., money), intellectual capital (i.e., expertise) and social capital (resulting from the person's institutionalized relationships of mutual acquaintance) (Bourdieu, 1977). Agents can convert this capital into a fourth type of capital: symbolic capital, which is associated with the power to classify any of the other resources as valuable (Levina \& Vaast, 2005), including the ability to claim 'authoritative knowledge' (Suchman, 2002), which refers to knowledge that is taken to be legitimate, that can justify specific actions taken by people engaged in accomplishing a task. Thus, in this viewpoint, assumptions about who holds relevant knowledge often replace the known reality.

Through practice, agents differentiate themselves from agents from other fields. Sustained intra-field collaboration leads to boundaries since different fields of practice usually do not share the same sets of values and interests (Levina \& Vaast, 2005). Knowledge sharing across boundaries will be more or less challenging, depending on the complexity of knowledge at the boundary, which depends on three relational properties: difference, dependence, and novelty (Carlile, 2004). Difference may exist either in the amount of knowledge accumulated or in the degree of specialization of knowledge within each field of practice. As the difference increases, so does the amount of effort required to share knowledge. The effect of difference, however, is contingent upon the degree of dependence among the fields. Low dependence implies that "difference is of no consequence" (Carlile, 2004, p. 556). Novelty is an attribute of the circumstances that call for knowledge sharing. When novelty is present, "there is often a lack of common knowledge to adequately share and assess domain specific knowledge at a boundary" (Carlile, 2004, p. 557).

Given these three properties, a boundary is said to be syntactic when differences and dependencies among practices at the boundary are known. In this case, an effective knowledge-sharing process transfers knowledge across a boundary through the creation and use of shared repositories and taxonomies (Carlile, 2002). An increase in novelty-in terms of new agents and/or new requirements-renders "some differences and dependencies unclear or some meanings ambiguous" (Carlile, 2004, p. 558). In such a situation, the boundary becomes semantic and the effective knowledge-sharing process is one of transfer followed by a translation, i.e., dealing with interpretive differences by creating shared meaning. A pragmatic boundary emerges when agents have different interests, and political consequences may arise from the differences and dependencies at the boundary (Carlile, 2002). In this case, transfer and translation will be used for sharing knowledge. To alleviate these consequences, an additional knowledge sharing process is required, one of knowledge transformation, in which individuals "learn, negotiate, and alter the current knowledge and create new knowledge to resolve the consequences identified" (Carlile, 2002, p. 455). In this situation, effective knowledge sharing requires agents to alter part of their existing knowledge as they engage in a process of knowledge transformation (Carlile, 2004).

In addition to knowledge sharing processes, boundary objects and boundary spanners (Levina \& Vaast, 2005) 
can contribute to knowledge sharing. Boundary objects are artefacts, such as prototypes and design drawings (Karsten, Lyytinen, Hurskainen, \& Koskelainen, 2001) and information systems (Schultze \& Boland, 2000) that contribute establishing a shared context. Effective boundary objects have three characteristics (Carlile, 2002, pp. 451-452). When used for knowledge transfer, a boundary object must create "a shared syntax or language for individuals to represent their knowledge." When problem interpretations differ, an effective boundary object should provide "concrete means for individuals to learn about their differences and dependencies across a given boundary." When political consequences are envisioned and negotiation is required, an effective boundary object will foster "a process where individuals can jointly transform their knowledge."

Boundary spanners are agents who perform the role of "knowledge brokers" (Pawlowski \& Robey, 2004) or "translators" (Yanow, 2000), implying that they assess knowledge at the boundary, and select the knowledge they consider pertinent. When boundary spanners are involved in change initiatives across boundaries, such as PMI, they engage in a role of change agent. Their mandate is to reconfigure, if not remove, boundaries for collaborative work to flow efficiently. Boundary spanners may be nominated by management, or may emerge during the process of cross-boundary knowledge sharing. To be effective they must be viewed as legitimate participants in the fields of practice being spanned (Levina \& Vaast, 2005).

\subsection{Organizational Identity in a Post-Merger Context}

The PMI literature suggests organizational identity as one of the main factors that affect merger outcomes (Chreim, 2007; Clark et al., 2010; Langley et al., 2012; Vieru \& Rivard, 2014b). Organizational identity constitutes a mental representation of how organizational members define themselves as a social group in terms of practices, norms, and values and how they see themselves as different from members of other organizations. It reflects the shared understanding of an organization's norms, values and practices (Corley \& Gioia, 2004). Through continuous interaction, organizational members reconstruct their organizational identity through interpretive schemes in order to provide meaning to their experiences as part of their membership of a specific organization (Dutton, Dukerich, \& Harquail, 1994). The more an individual conceives of the self in terms of the membership of an organization, the more the individual's attitudes and behavior are governed by this organizational membership (Langley et al., 2012). Complex organizational changes such as mergers trigger a process of change of the organizational identity (Corley \& Gioia, 2004; Vieru \& Rivard, 2014b). This offers one explanation for why mergers tend to create significant resistance among employees (Empson, 2004).

\section{A Practice-Based Framework of Knowledge Sharing in Post-Merger IS Integration Settings}

\subsection{Overview}

Our theoretical framework (1) explains how the PMI approach adopted to realize a merger influences the conditions under which organizations engage in IS integration in view of supporting the new organization's practices and (2) conjectures about effective knowledge sharing processes and boundary objects, the role that boundary spanners are expected to play if they are to be effective and the potential discursive strategies used by boundary spanners.

The framework, detailed in Table 1, is based on two scope conditions. First, the fields of practice under consideration are organizations that merge under a given PMI approach. Depending on the approach, the PMI phase creates a context in which actors from pre-merger fields of practice need to overcome their idiosyncrasies in terms of knowledge embedded in practices if they want to share knowledge in view of IS integration.

Second, we adopt Doty and Glick's (1994) definition of typologies, wherein ideal-types "are intended to provide an abstract model [...] to represent organizational forms that might exist rather than existing organizations. Thus, empirical examples of ideal type organizations are expected to be very rare or non-existent [...] actual organizations may be more or less similar to an ideal type, but they should not be assigned to one of the ideal types in the typology" (Doty \& Glick, 1994, p. 233). This implies that readers should not expect that the examples of actual mergers used to illustrate the framework would possess all the characteristics associated with a given ideal-type.

The framework operates as follows. A given PMI approach entails certain levels of organizational and IS integration. Organizational integration is defined in a PMI context as the combination of some or all of the previously separate "structures, business processes, systems, people, and cultures of the two firms into a unified whole" (Tanriverdi \& Uysal, 2011, p. 704). We suggest that the level of planned integration influences the level of knowledge complexity at the boundary between fields of practice, thus creating demands on the types of knowledge sharing processes-performed with boundary objects-that the agents involved in an IS integration will require for appropriate knowledge sharing. We also posit that the level of knowledge complexity at the boundary 
and the pre-merger organizational identities will influence the role of effective boundary spanners and their potential engagement in cross-boundary symbolic discourse strategies.

The framework can be summarized in the following propositions:

Proposition 1: Under a PMI preservation approach, organizational identity, organizational practices, and the ISs of the merging parties will be preserved. Effective boundary spanners will use boundary objects to transfer knowledge across syntactic boundaries. They will engage in discourses of legitimation of the preservation of boundaries.

Table 1. Key characteristics of the IS integration in a PMI context

\begin{tabular}{|c|c|c|c|c|c|c|c|c|}
\hline $\begin{array}{l}\text { Ideal-type } \\
\text { PMI } \\
\text { Approach }\end{array}$ & $\begin{array}{l}\text { Object of } \\
\text { Integration }\end{array}$ & $\begin{array}{l}\text { Most Likely } \\
\text { Type of } \\
\text { Knowledge } \\
\text { Boundary }\end{array}$ & $\begin{array}{l}\text { Relational } \\
\text { Properties }\end{array}$ & $\begin{array}{l}\text { Effective } \\
\text { Knowledge } \\
\text { Sharing } \\
\text { Processes } \\
\end{array}$ & $\begin{array}{l}\text { Effective } \\
\text { Boundary } \\
\text { Objects }\end{array}$ & $\begin{array}{l}\text { Org. } \\
\text { Identity }\end{array}$ & $\begin{array}{l}\text { Required Role of } \\
\text { Effective } \\
\text { Boundary } \\
\text { Spanners }\end{array}$ & $\begin{array}{l}\text { Symbolic } \\
\text { Boundary } \\
\text { Spanners } \\
\text { Discourse } \\
\end{array}$ \\
\hline Preservation & $\begin{array}{l}\text { Data } \\
\text { and IS }\end{array}$ & Syntactic & $\begin{array}{l}\text { Difference is } \\
\text { of no } \\
\text { consequence } \\
\text { Dependence } \\
\text { is } \\
\text { non-existent } \\
\text { Novelty is } \\
\text { low }\end{array}$ & Transfer & $\begin{array}{l}\text { Syntactica } \\
1 \text { tools }\end{array}$ & Status quo & $\begin{array}{l}\text { Establish } \\
\text { communication } \\
\text { channels to foster } \\
\text { knowledge } \\
\text { transfer }\end{array}$ & $\begin{array}{l}\text { Legitimizatio } \\
\mathrm{n} \text { of } \\
\text { boundaries }\end{array}$ \\
\hline Symbiosis & $\begin{array}{l}\text { Practi } \\
\text { ces } \\
\text { and IS }\end{array}$ & Semantic & $\begin{array}{l}\text { Difference is } \\
\text { idiosyncratic } \\
\text { Dependence } \\
\text { is high } \\
\text { Novelty is } \\
\text { medium }\end{array}$ & $\begin{array}{l}\text { Transfer and } \\
\text { Translation }\end{array}$ & $\begin{array}{l}\text { Syntactica } \\
1 \text { tools } \\
\text { Standardi } \\
\text { zed forms } \\
\text { and } \\
\text { methods }\end{array}$ & Negotiated & $\begin{array}{l}\text { Mitigate agents' } \\
\text { status differences } \\
\text { to establish } \\
\text { effective } \\
\text { knowledge } \\
\text { sharing }\end{array}$ & $\begin{array}{l}\text { Authoritative } \\
\text { knowledge }\end{array}$ \\
\hline Transformatio & $\begin{array}{l}\text { Practi } \\
\text { ces } \\
\text { and IS }\end{array}$ & Pragmatic & $\begin{array}{l}\text { Difference is } \\
\text { idiosyncratic } \\
\text { Dependence } \\
\text { is high } \\
\text { Novelty is } \\
\text { high }\end{array}$ & $\begin{array}{l}\text { Transfer, } \\
\text { Translation }\end{array}$ & $\begin{array}{l}\text { Syntactica } \\
1 \text { tools, } \\
\text { Standardi } \\
\text { zed forms }\end{array}$ & Transitional & $\begin{array}{l}\text { On each site of } \\
\text { the boundary they } \\
\text { will try to create } \\
\text { ways to convey } \\
\text { the image of a } \\
\text { new } \\
\text { organizational } \\
\text { identity }\end{array}$ & $\begin{array}{l}\text { Authoritative } \\
\text { knowledge }\end{array}$ \\
\hline
\end{tabular}

Proposition 2: When a symbiotic PMI approach is adopted, the ISs and practices will have to be integrated as to leverage the best of all merging entities. Effective boundary spanners will use boundary objects to transfer and translate knowledge across semantic boundaries. They will engage in organizational identity negotiation by claiming authoritative knowledge.

Proposition 3: Under a transformation PMI approach, all ISs and practices will be replaced by new ones and a new organizational identity will be created. Due to a high level of knowledge complexity at the boundary, effective boundary spanners will use boundary objects to transfer, translate, and transform knowledge across pragmatic boundaries. They will also make claims of authoritative knowledge in an effort to build a common organizational identity. 
Proposition 4: An absorption PMI approach entails the absorbing party will have to impose its ISs and practices. Due to a high level of knowledge complexity at the boundary, effective boundary spanners from the absorbing entity will use boundary objects to transfer, translate, and transform knowledge across pragmatic boundaries. They will also engage in discourses of legitimation of the new boundary arrangements.

To illustrate the tenets of our framework, and assess its soundness we use existing case studies from the academic literature that present rich post-merger IS integration data (Rivard, 2014).

\subsection{Preservation Approach, a Syntactic Boundary}

Under a preservation approach, organizational identities, business processes, and practices of the merging parties are to be preserved. Although the level of inter-organizational integration is low, common ISs are needed to integrate some of the data from the merging entities. These systems are likely to play the role of "bridges" between existing ISs, so as to provide a common lexicon to process and transfer information.

For example, when Danisco, a Danish company with a growth-by-acquisition strategy, merged with Genencor, a US-based biotechnology company, management decided to preserve the Genencor's ISs that were supporting research activities and supply chain management (Yetton et al., 2013). During negotiations Danisco discovered that, from a business point of view it made more sense to keep the existing Genencor's systems than trying to replace or re-configure them to align their embedded processes to Danisco's standards. In such a situation, the dependence between the parties involved in the IS integration is very low, because the pre-merger structures will be preserved. Important differences may exist in the meaning of terms employed within each merging organization. For instance, merging firms might follow different accounting standards or apply different levels of freedom for depreciation or valuation. Yet, because independence between the parties will be preserved, differences in practices are of no consequences (Carlile, 2004). Thus, as shown in the case of Danisco-Genencor merger, transition planning still require a good understanding of IT resources existing in each side of the boundaries between the merging entities (Yetton et al., 2013).

In this context, agents involved in IS integration are faced with a syntactic boundary, across which the effective knowledge sharing process is one of knowledge transfer to create a common lexicon. In the case of Danisco, this was necessary during due diligence to be able to extend its IT capabilities to integrate the preserved Genencor's data applications. Here, the effective boundary objects used by agents are likely to be syntactical tools, including repositories (e.g., shared databases), which provide an integrated viewpoint for developing norms for practices. Danisco developed a scalable SAP-based IT platform capable to be extended with the unique Genencor IT resources that needed to be preserved during the PMI process in "a co-existence IT integration process" (Yetton et al., 2013, p. 31). Under such circumstances, to be effective, the boundary spanners will have to build efficient communication channels to transfer knowledge by creating an enticing context for collaboration (e.g., financial rewards, promotion) between the agents on each side of the boundary. This will be necessary in order to alleviate the challenges that might arise during the creation of the new common lexicon. The Danisco IT team actively participated in the negotiation phase. The Danisco CIO was a manager with proven track record of great respect among employees at Danisco. His boundary discourse of legitimation of the preservation of boundaries at the outset of the PMI phase "avoided tense discussions about the future of IT" (Yetton et al., 2013, p. 28). We conjecture that this type of discourse represents "legitimation by reference to authority" (Vaara, Tienari, \& Laurila, 2006, p. 799). Danisco CIO had the vested institutional authority and the necessary accumulated symbolic capital to deliver a successful symbolic boundary discourse.

\subsection{Symbiotic Approach, a Semantic Boundary}

A symbiotic PMI approach involves a slow process of a gradual blending of best practices from the merging organizations that become interdependent. Thus, the process of integration entails the combination of the "best" identified practices and ISs from each merging entity, if necessary, the implementation of new common ISs that will support new business processes. Take the example of the merger of Sallie Mae and USA Group, both student-loans US companies (Brown et al., 2003). In order to leverage the "best of both" companies, Sallie Mae, who acquired USA Group, decided to combine the software and hardware as well as IT expertise from both merging entities. The new management decided to consolidate the two data centers by relocating Sallie Mae's data center in the USA Group data center. It also appointed an IT team from each merging company to conduct comparative analyses of similar systems to determine which should be retained and which should be decommissioned. Decisions were based on negotiations and trade-offs and in the end Sallie Mae's loan servicing application and USA Group's back-office systems (PeopleSoft modules) were kept for use by the new organization. 
Although the degree of difference of knowledge between the merging parties influences the complexity of knowledge at the boundary, this influence is likely to be limited to the time required for the common IS to be configured and put into production. The greater the difference in the amount and in the degree of knowledge within each field of practice, the longer it will take to configure and successfully implement a common IS. Here, the dependence between the merging practices is high, as the configuration of ISs to support the processes of the merged organization is likely to require collaboration in terms of explaining one organization's business processes, understanding those of the other organization, and ultimately coming up with a single process.

Novelty of the knowledge-sharing context is not very high because, as per the approach, practices are gradually modified. Here, the boundary is semantic with some differences being known at the outset and others emerging during PMI. Agents are likely to use boundary objects that support first, the process of knowledge transfer and then second, the process of translation of the differences and learning about dependencies at the boundary. Such boundary objects comprise repositories (for transfer) and standardized methods (for translation) that may include standardized information infrastructure-based technologies, such as Lotus Notes (Hanseth \& Braa, 2001), or PowerPoint slides and three-year net present value (NPV) analyses like in the case of Sallie Mae-USA Group merger (Brown et al., 2003) to assess their knowledge differences and dependencies and identify common meanings. The latter type of boundary object is efficient for semantic boundaries because it can be "local and universal in the same time" (Hanseth \& Braa, 2001, p. 289). For instance, Lotus Notes provides a standard platform that offers a structured space where organizational members can specify their understanding of differences and dependencies between the fields of practice.

The greater the complexity of knowledge at the boundary, the harder it is for the boundary spanners to identify common ground for knowledge sharing. Notwithstanding, the symbiotic approach is an evolutionary path toward PMI by trying to avoid the conflicting tensions between the merging parties and by ensuring simultaneous boundary preservation and boundary permeability. Here, although the initial goal is to develop a convergent organizational identity, in order to be effective, boundary spanners might try providing accommodations for the members of the merging entities by using their symbolic capital. For example, in their study of hospital mergers, Langley et al. (2012) found that the boundary spanners and the employees negotiated different aspects of sameness and differences between the old and the new identities. By offering trade-offs (maintaining several aspects of the pre-merger identity) "the management paradoxically offered resources that might enable group members to more easily adapt their identity constructions to their new situation" (Langley et al., 2012, p. 163).

Successful knowledge sharing was considered key for a smooth integration of the systems in the case of Sallie Mae-USA Group merger. On the one hand, due to the data center relocation, some of the Sallie Mae employees were contemplating the decision to take the offered severance packages and look for another job. On the other hand, the retention of Sallie Mae's old loan servicing application was considered "a bitter pill" to swallow by the USA Group employees (Brown et al., 2003, p. 19). To mitigate this and ensure the creation of an environment for effective knowledge sharing, upper management nominated several IT managers from both firms to supervise the integration. These boundary spanners considered their "established working relationships" as being "secret weapons" during the IS integration (Brown et al., 2003, p. 22). This suggests that by using their accumulated symbolic capital they were able to claim authoritative knowledge to "rally the troops" (p. 22) and avoid, what one of the IT manager metaphorically states, the situation when "a jockey that pulls too hard on the reins will never have a winning horse" (p. 21).

\subsection{Absorption and Transformation, Pragmatic Boundaries}

When PMI involves dramatic changes in the practices of one merging organization (the absorbed party in the absorption approach) or all merging entities (in the transformation approach), the combined organization will reflect a unique set of practices, be they those of the absorbing organization or totally new common practices. In the Absorption approach, the 'absorbing' party will retain, as much as possible, their existing practices and ISs. The merger could also represent an opportunity for the 'absorbing' party to implement new ISs that would enable the post-merger extended business processes. In the Transformation approach, the integration process entails the replacement of most of the existing practices and ISs.

For example, in 2000, after acquiring the France-based Rhodia, Danisco, a Danish company, decided to implement its own IT-enabled standardized business processes in the Rhodia business units by expanding Danisco's "ready-to-acquire" IT platform (Yetton et al., 2013). Danisco's absorption approach enabled the new company to operate with the same set of Danisco's "standardized business processes supporting more products, production facilities, employees and geographical locations" (p. 26).

In another case, Suncorp, which emerged from the merger of two Australian financial institutions in 2007, 
Suncorp and Promina, aimed at uniting two "disparate IT organizations with a new common vision: to become a world class IT function" (Seddon et al., 2010, p. 1079). Their intent was likely a transformation PMI approach. It has been suggested that this approach is not efficient because the available PMI time is often insufficient and the identification of the necessary ISs could create resistance and political struggle (Wijnhoven et al., 2006; Vaara \& Monin, 2010). Suncorp and Promina had multiple IT applications, each with its own practices and knowledge bases. Facing dramatic changes in practices and organizational identity, and not understanding the dependencies between the new practices and the business processes, the management hired Jeff Smith as the new Suncorp CIO. Smith had accumulated symbolic capital by successfully engaging in major IS integrations over the years. Smith adopted in a two-step approach. First, he kept duplicate legacy systems at each merging entity. Second he focused on promoting in-house IS innovation by introducing Agile development. This led the new organization into a successful three-year transition from a nearly preservation approach at the outset to a transformation approach represented by new, cross-boundary innovative systems that replaced the legacy applications. While some members of Suncorp and Promina upper management favoured a quick, total consolidation (transformation) of the ISs, the CIO's focus was first on people and processes and only later on the systems. His vision was based on the underlying Agile philosophy that he considered to be "the most effective way to develop new IT-based systems" and to provide "a future vision that could enthuse staff from both IT organizations" (Seddon et al., 2010, p. 1080).

In both cases (absorption and transformation) the knowledge boundary was pragmatic. Novelty of the knowledge-sharing context and the level of differences and dependencies among practices were high for all parties. At the outset of the PMI, Rhodia's practices and their knowledge bases were completely different than Danisco's. It is likely that, in order to successfully absorb Rhodia's ISs, the members from both organizations were heavily dependent on each other in order to effectively integrate the ISs and the rest of the IT resources. In the case of Suncorp and Promina, the two companies were so different in organizational knowledge bases (high level of differences), that it can be surmised that implementing new practices and new ISs triggered a daunting endeavour for the members of the merging entities and involved a high level of dependency among all involved actors.

Because of the high level of knowledge complexity at the boundary, knowledge sharing required a process of transfer, followed by translation and then transformation of the knowledge that people on each side of the boundary have accumulated and considered being 'at stake'. An efficient knowledge sharing process at a pragmatic boundary sometimes requires multiple iterations (Carlile, 2004). Agents might need to go back and forth between translation and transformation processes in an iterative way that enables them "to get better at identifying what differences and dependencies are of consequence at the boundary; they improve at collectively developing a more adequate common lexicon, meaning, and interests" (Carlile, 2004, p. 563).

Both transformation and absorption create a pragmatic knowledge boundary. Hence, the agents involved in cross-boundary knowledge sharing engage in a process of knowledge transformation. However, we suggest that knowledge sharing is difficult under both approaches.

In the absorption approach, the 'absorbing' party will have to share their knowledge with their counterparts, while the 'absorbed' party will be obliged to transform their practices to resemble that of the former. These changes will have a serious impact on the 'absorbed' members' organizational identity. However, 'absorbed' members' evaluation of how the new identity would affect their pre-merger practices may lead to the acceptance of-or resistance to-the changes imposed by the merger. For example, individuals that belong to an organization that provides them with self-enhancement following absorption will more likely to promote the new identity (Dutton et al., 1994). Others will resist the changes and will seek ways to retain or recapture some form of organizational identity distinctiveness (Chreim, 2007).

In an absorption approach, the 'absorbing party' is likely to want to preserve its existing practices and implement new ISs that will enable them. During IS integration efforts, effective boundary spanners from the absorbing party are expected to try to legitimize their knowledge base and organizational identity in the eyes of the 'others' in order to ensure efficient knowledge sharing. For example, we can conjecture that, as in the other Danisco merger (with Genencor), the Danisco CIO efficiently played his boundary spanner role (albeit now as an 'absorber' and not as a 'preserver') by using his accumulated symbolic capital. His boundary discourse of legitimation of dissolving the boundaries and absorbing Rhodia's ISs in front of Rhodia's management was based on statements such as Danisco was "a global company with standardized processes" and that "this strategy was not negotiable" (Yetton et al., 2013, p. 26). This type of discourse represents again a "legitimation by reference to authority" (Vaara et al., 2006, p. 799). 
In the transformation approach, the organizational members from the merging entities will be asked to change their former practices and accept a new identity and other organizational attributes. In this situation, one can assume that a temporary identity, called transitional identity-an interim mindset held by members about what their organizational identity was becoming-that would maintain some aspects of the pre-merger identity, while simultaneously facilitating progress toward a completely new identity, constitutes a practical means for advancing the transformation process (Clark et al., 2010). Agents from merging entities must revise their existing organizational identities by building new, and more importantly, shared ways of making sense of who they are in a common new organizational context. Under these circumstances, we expect that effective boundary spanners, on either side of the boundary, will try to influence agents' mental frameworks in an effort to build a common identity by communicating a reliable image (transitional identity) to them that involves playing down their differences and emphasizing their emerging identity as members of a new organization. This will create an efficient environment for knowledge sharing. Thus, manifestations of symbolic capital will be seen in boundary spanners' activities. The idea of engaging in a movement toward a shared identity by means of a transitional identity is to create a mechanism for conveying the image of a new identity in non-threatening terms that will influence "the construction of a way of understanding that both sides could accept" (Clark et al., 2010, p. 427)

In the case of Suncorp, we infer that the new CIO, acting as a boundary spanner, decided to implement a transitional identity represented by the Agile approach of seeing IS development practices. For him, Agile "gave everyone a new vision. It said 'let's go here'. It was not tied to where you were. You were not talking about one group taking over another" (Seddon et al., 2010, p. 1080). We conjecture that the CIO used his symbolic capital and claimed authoritative knowledge when he personally met his IT managers to convince them that collaboration needs to be based on Agile's knowledge sharing pillars: "listening skills" and leveraging "other people's knowledge" (p. 1081). This vision energized the IT staff at both organizations, fostered innovation and paved the way to a complete and seamless IS integration three years later.

While repositories and standard methods are considered effective boundary objects for knowledge transfer and translation respectively, models are deemed to be effective boundary objects for a pragmatic boundary as they enable "a process where individuals can jointly transform their knowledge" (Carlile, 2002, p. 452) and provide an infrastructure on which new forms of knowledge are produced and shared. In an IS integration context, these may include prototyping and modeling technologies (Leonard-Barton, 1995) that represent technologies that are able to integrate new forms of knowledge that are jointly created at the boundary. To cultivate innovation at Suncorp, the CIO promoted and convinced the IT staff to use open-source software technologies to develop new systems (Open Net Environment for the new identity management and Drools to design the new underwriting services application).

\section{Conclusions and Avenues for Future Research}

The IS literature on PMI suggests that IS integration is difficult, mainly because of the incompatibility of the merging parties' ISs (Vieru \& Rivard, 2014b) and differences in practices and members' organizational identities (Langley et al., 2012). Yet, although research stresses the importance of the role played by ISs in supporting the combined organizations, no studies have examined the challenges for integrating ISs during PMI.

In this study we focused on the issue of knowledge sharing during post-merger IS integration, and we developed a framework based on a practice perspective of knowledge and on the notion of organizational identity. We posited that different ideal-types of PMI approaches may influence the nature of the knowledge boundary and the pre-merger organizational identity; thus creating demands on the types of knowledge sharing processes and boundary objects that the agents involved in an IS integration initiatives will require for appropriate knowledge sharing as well as on the role played by boundary spanners. We also suggested that agents, as boundary spanners, will try to use their accumulated symbolic capital in order to make claims about who holds relevant knowledge and legitimize the new boundary arrangements.

Prior work stresses the importance of efficiently collaborating and sharing knowledge during PMI (Empson, 2001; Vieru \& Rivard, 2014b). However, there is little theoretical development on the challenges agents encounter when they need to share knowledge across the boundaries between the merging entities. Therefore, our work makes several contributions. First, it contributes to the literature on PMI by proposing a framework that explains how a given PMI approach influences the conditions surrounding the IS integration and conjectures about effective knowledge sharing processes, boundary objects and the role that boundary spanners are expected to play if they are to be effective.

Second, our framework contributes to the growing body of literature on "knowledge-in-practice" sharing (Orlikowski, 2002; McIver et al., 2013; Jarrahi \& Sawyer, 2015). Our work suggests that knowledge sharing 
during post-merger IS integration is challenging; investigating the differences and dependencies in these collaborative efforts constitutes an important first step towards a comprehensive understanding of knowledge sharing during PMI. We propose our framework as a foundation for developing empirical analyses of cross-boundary knowledge sharing. Third, it has been suggested that post-merger organizational change possibly entails the most potential for disruption because it brings a change in identity (Corley \& Gioia, 2004; Vieru \& Rivard, 2014b). A change in organizational identity impacts the practice-based identity of organizational members (Langley et al., 2012). Our framework suggests that-with the exception of the preservation approach boundary spanners, as change agents, will engage in symbolic discourses to provide legitimacy of change (boundary arrangements) and to foster a common identity-building process by discursively reconstructing actors' mind frames. Thus, our theorization work can be seen as a further encouragement to analyze emerging legitimation symbolic discourses (Vaara \& Monin, 2010) in different organizational change contexts.

For practitioners, our framework sheds light on employees' potential negative responses to IS integration efforts and the dangers of such resistance. Thus, cross-boundary knowledge sharing in a post-merger context involves the negotiation of multiple domains of knowledge by the members of a field of practice who usually have a limited understanding of domains besides their own-shared domain of knowledge. While there are certainly other topics that enlighten our understanding of IS integration in specific organizational contexts, we argue that differences in understandings of others' practices, organizational norms and symbols may have a significant impact on the process of IS integration during PMI.

Our work opens avenues for future research. First, although we illustrated our framework with rich cases culled from the PMI literature, it would be important to conduct in-depth case studies of mergers along each of the four PMI approaches to determine the extent of the framework's explanatory power and add to it. Second, it has been found that organizational members tend to reuse knowledge (Carlile, 2004), such that post-merger knowledge sharing can be, in part, attributed to path dependence. Future research on post-merger knowledge sharing needs to explicitly consider the path dependent nature of post-merger behaviours during empirical analyses.

\section{References}

Bourdieu, P. (1977). Outline of a theory of practice. Cambridge University Press. http://dx.doi.org/10.1017/CBO9780511812507

Brown, C. V., Clancy, G., \& Scholer, R. (2003). A post-merger IT integration success story: Sallie Mae. MIS Quarterly Executive, 2(1), 15-27.

Brown, J. S., \& Duguid, P. (2001). Knowledge and organization: A social-practice perspective. Organization Science, 12(2), 198-213. http://dx.doi.org/10.1287/orsc.12.2.198.10116

Brown, S. A., Dennis, A. R., Burley, D., \& Arling, P. (2013). Knowledge sharing and knowledge management system avoidance: The role of knowledge type and the social network in bypassing an organizational knowledge management system. Journal of the American Society for Information Science and Technology, 64(10), 2013-2023. http://dx.doi.org/10.1002/asi.22892

Carlile, P. (2002). A pragmatic view of knowledge and boundaries: Boundary objects in new product development. Organization Science, 13(4), 442-455. http://dx.doi.org/10.1287/orsc.13.4.442.2953

Carlile, P. (2004). Transferring, translating and transforming: An integrative framework for managing knowledge across boundaries. Organization Science, 15(5), 555-568. http://dx.doi.org/10.1287/orsc.1040.0094

Chreim, S. (2007). Social and temporal influences on interpretations of organizational identity and acquisition integration. Journal of Applied Behavioral Science, 43, 449-480. http://dx.doi.org/10.1177/0021886307307345

Clark, S. M., Gioia, D., Ketchen, D. Jr., \& Thomas, J. (2010). Transitional identity as a facilitator of organizational identity change in a merger. Administrative Science Quarterly, 55, 397-438. http://dx.doi.org/10.2189/asqu.2010.55.3.397

Cook, S. D. N., \& Brown, J. S. (1999). Bridging epistemologies: The generative dance between organizational knowledge and organizational knowing. Organization Science, 10(4), 381-400. http://dx.doi.org/10.1287/orsc.10.4.381

Corley, K., \& Gioia, D. (2004). Identity ambiguity and change in the wake of a corporate spin-off. Administrative Science Quarterly, 4, 173-208.

Doty, D., \& Glick, W. (1994). Typologies as a unique form of theory building: Toward improved understanding and modeling. Academy of Management Review, 19(2), 230-251. http://dx.doi.org/10.2307/258704 
Dutton, J., Dukerich, J., \& Harquail, C. (1994). Organizational images and member identification. Administrative Science Quarterly, 39, 239-263. http://dx.doi.org/10.2307/2393235

Empson, L. (2001). Fear of exploitation and fear of contamination: Impediments to knowledge transfer in mergers between professional service firms. Human Relations, 54(7), 839-862. http://dx.doi.org/10.1177/0018726701547003

Empson, L. (2004). Organizational identity change: Managerial regulation and member identification in an accounting firm acquisition. Accounting, Organizations and Society 29, 759-781. http://dx.doi.org/10.1016/j.aos.2004.04.002

Graebner, M. (2004). Momentum and serendipity: How acquired leaders create value in the integration of technology firms. Strategic Management Journal, 25, 751-777. http://dx.doi.org/10.1002/smj.419

Gregor, S. (2006). The nature of theory in information systems. MIS Quarterly, 30(3), 611-642.

Hanseth, O., \& Braa, K. (2001). Hunting for the treasure at the end of the rainbow: Standardizing corporate IT infrastructure. Computer Supported Cooperative Work, 10, 261-292. http://dx.doi.org/10.1023/a:1012637309336

Haspeslagh, P., \& Jemison, D. (1991). Managing acquisitions: Creating value through corporate renewal. The Free Press, NYC.

Henningsson, S., \& Yetton, P. (2011). Managing the IT integration of acquisitions by multi-business organizations. Proceedings of the $32^{\text {nd }}$ International Conference on Information Systems.

Ibarra, H. (1993). Personal networks of women and minorities in management: A conceptual framework. Academy of Management Review, 18(1), 56-87. http://dx.doi.org/10.2307/258823

Jarrahi, M. H., \& Sawyer, S. (2015). Theorizing on the take - up of social technologies, organizational policies and norms, and consultants' knowledge-sharing practices. Journal of the Association for Information Science and Technology, 66(1), 162-179. http://dx.doi.org/10.1002/asi.23161

Karsten, H., Lyytinen, K., Hurskainen, M., \& Koskelainen, T. (2001). Crossing boundaries and conscripting participation: Representing and integrating knowledge in a paper machinery project. European Journal of Information System, 10(2), 89-98. http://dx.doi.org/10.1057/palgrave.ejis.3000395

Langley, A., Golden-Biddle, K., Reay, T., Denis, J. L., Lamothe, L., \& Gervais, J. (2012). Identity struggle in merging organizations: Renegotiating the sameness-difference dialectic. Journal of Applied Behavioral Science, 48(2), 135-167. http://dx.doi.org/10.1177/0021886312438857

Larsson, R., \& Finkelstein, S. (1999). Integrating strategic, organizational, and human resource perspectives on mergers and acquisitions: A case survey of synergy realization. Organization Science, 10(1), 1-26. http://dx.doi.org/10.1287/orsc.10.1.1

Leonard-Barton, D. (1995). Wellsprings of knowledge: Building and sustaining the sources of innovation. Boston: HBS Press.

Levina, N., \& Vaast, E. (2005). The emergence of boundary spanning competence in practice: Implications for implementation and use of information systems. MIS Quarterly, 9(2), 335-369.

Levina, N., \& Vaast, E. (2008). Innovating or doing as told? Status differences and overlapping boundaries in offshore collaboration. MIS Quarterly, 32(2), 307-329. http://dx.doi.org/10.2139/ssrn.1136880

Luna-Reyes, L. F., Zhang, J., Gil-Garcia, J. R., \& Cresswell, A. M. (2005). Information systems development as emergent socio-technical change: A practice approach. European Journal of Information Systems, 14(1), 93-105. http://dx.doi.org/10.1057/palgrave.ejis.3000524

Marks, M. L., \& Mirvis, P. H. (2001). Making mergers and acquisitions work: Strategic and psychological $\begin{array}{llll}\text { preparation. Academy of } & \text { Management }\end{array}$ http://dx.doi.org/10.5465/AME.2001.4614947

McIver, D., Lengnick-Hall, C., Lengnick-Hall, M., \& Ramachandran, I. (2013). Understanding work and knowledge management from a knowledge-in-practice perspective. Academy of Management Review, 38(4), 597-620. http://dx.doi.org/10.5465/amr.2011.0266

Mehta, M., \& Hirschheim, R. (2007). Strategic alignment in mergers and acquisitions: Theorizing IS integration decision making. Journal of the Association for Information Systems, 8(3), 143-174. 
Merali, Y., \& McKiernan, P. (1993). The strategic positioning of information systems in post-acquisition management. The Journal of Strategic Information Systems, 2(2), 105-124. http://dx.doi.org/10.1016/0963-8687(93)90003-S

Orlikowski, W. J. (2002). Knowing in practice: Enacting a collective capability in distributed organizing. Organization Science, 13(3), 249-273. http://dx.doi.org/10.1287/orsc.13.3.249.2776

Pawlowski, S., \& Robey, D. (2004). Bridging user organizations: Knowledge brokering and the work of information technology professionals. MIS Quarterly, 28(4), 645-673.

Rivard, S. (2014). Editor's comments: The ions of construction. MIS Quarterly, 38(2), 3-13.

Schultze, U., \& Boland, R. (2000). Knowledge management technology and the reproduction of knowledge work

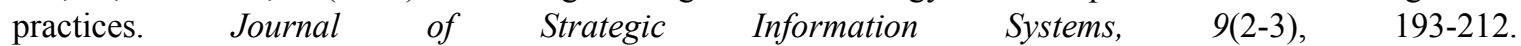
http://dx.doi.org/10.1016/S0963-8687(00)00043-3

Schweizer, L. (2005). Organizational integration of acquired biotechnology companies into pharmaceutical companies: The need for a hybrid approach. Academy of Management Journal, 48(6), 1051-1074. http://dx.doi.org/10.5465/AMJ.2005.19573109

Seddon, P. B., Reynolds, P., \& Willcocks, L. (2010). Post-merger IT integration: A comparison of two case studies. Proceedings of PACIS.

Suchman, L. (2002). Practice-Based Design of Information Systems: Notes from the Hyper-developed World. The Information Society, 18, 139-144. http://dx.doi.org/10.1080/01972240290075066

Tanriverdi, H., \& Uysal, V. B. (2011). Cross-business information technology integration and acquirer value creation in corporate mergers and acquisitions. Information Systems Research, 22(4), 703-720. http://dx.doi.org/10.1287/isre.1090.0250

Vaara, E., \& Monin, P. (2010). A recursive perspective on discursive legitimation and organizational action in mergers and acquisitions. Organization Science, 21(1), 3-22. http://dx.doi.org/10.1287/orsc.1080.0394

Vaara, E., Tienari, J., \& Laurila, J. (2006). Pulp and paper fiction: On the discursive legitimation of global industrial restructuring. Organization Studies, 27(6), 789-813. http://dx.doi.org/10.1177/0170840606061071

Vieru, D., \& Rivard, S. (2014). Organizational identity challenges in a post-merger context: A case study of an information system implementation project. International Journal of Information Management, 34(3), 381-386. http://dx.doi.org/10.1016/j.ijinfomgt.2014.02.001

Vieru, D., Rivard, S., \& Dutot, V. (2014). Insights from a review of the literature on post-merger information systems/information technology integration. International Business Research, 7(7), 23-36. http://dx.doi.org/10.5539/ibr.v7n7p23

Weber, Y., \& Tarba, S. Y. (2012). Mergers and acquisitions process: The use of corporate culture analysis. Cross Cultural Management: An International Journal, 19(3), 288-303. http://dx.doi.org/10.1108/13527601211247053

Wijnhoven, F., Spil, T., Stegwee, R., \& Fa, R. T. (2006). Post-merger IT integration strategies: An IT alignment

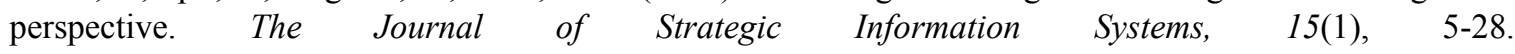
http://dx.doi.org/10.1016/j.jsis.2005.07.002

Yanow, D. (2000). Seeing organizational learning: A 'cultural' view. Organization, 7(2), 247-268. http://dx.doi.org/10.1177/135050840072003

Yetton, P., Henningsson, S., \& Bjorn-Andersen, N. (2013). Ready to acquire: The IT resources required for a growth-by-acquisition business strategy. MIS Quarterly Executive, 12(1), 19-35.

Yuan, Y. C., Zhao, X., Liao, Q., \& Chi, C. (2013). The use of different information and communication technologies to support knowledge sharing in organizations: From e-mail to micro-blogging. Journal of the American Society for Information Science and Technology, 64(8), 1659-1670. http://dx.doi.org/10.1002/asi.22863

\section{Copyrights}

Copyright for this article is retained by the author(s), with first publication rights granted to the journal.

This is an open-access article distributed under the terms and conditions of the Creative Commons Attribution license (http://creativecommons.org/licenses/by/3.0/). 